\title{
Perspective Taking, Environmental Concern and the Moderating Role of Dispositional Empathy
}

\author{
Verónica Sevillano, Juan I. Aragonés, Complutense University of Madrid, \\ Spain, Wesley Schultz California State University, San Marcos
}

\begin{abstract}
This article examines the impact of visual images and perspective taking on concern for environmental problems. Participants in the experiment were 193 university students. Results replicated earlier results showing that perspective taking, combined with images of animals harmed by nature, caused an increase in biospheric environmental concerns. In addition, results showed that the empathic dimension of personal distress moderated the relationship between kind of image and kind of perspective on both biospheric and egoistic environmental concerns. Results about the lack of other moderating effects are discussed.
\end{abstract}

Keywords: environmental concern; empathy; perspective taking; environmental values

\footnotetext{
Authors' Note: Verónica Sevillano and Juan I. Aragonés, Facultad de Psicología, Universidad Complutense de Madrid, Spain. P. Wesley Schultz, Department of Psychology, California State University, San Marcos. This research was supported by a project of Ministerio de Ciencia y Tecnología (MCyT), BSO2002-03459 and by a FPU grant of Ministerio de Ciencia y Tecnología to Veronica Sevillano, AP2002-0808. We thank Ignacio Serrano-Pedraza for prepar- ing the figures. Correspondence concerning this article should be addressed to Verónica Sevillano, Facultad de Psicología, Universidad Complutense de Madrid. Campus de Somosaguas, 28223, Madrid, Spain. E-mail:vsevilla@psi.ucm.es
} 
Studies of environmental attitudes have a long history in environmental psychology. There is a large volume of research examining the ways in which people think about environmental issues, the types of concerns that individuals hold about environmental problems, and the relationship between environmental attitudes and behavior. Originally, research on environmental attitudes and proenvironmental behavior was developed from a sociological point of view (Dunlap \& Van Liere, 1978; Milbrath, 1986), emphasizing the role of society in generating and maintaining environmental problems.

Consequently, constructs such as the new ecological paradigm, worldview, and anthropocentrism emerged from this body of work, among others. More recently, theoretical developments and a number of empirical studies of environmental attitudes have focused on a more psychological perspective (e.g. Kaiser \& Fuhrer, 2003; Schultz, 2001; Stern \& Dietz, 1994; Thompson \& Barton, 1994; Uzzell, 2000).

One line of psychological work has examined the values and motives that underlie environmental attitudes. This work has shown that different values are associated with different attitudes about environmental problems. Thompson and Barton (1994) distinguish two kinds of values under- lying environmental attitudes: ecocentric, which empathizes the value of nature itself, and anthropocentric, which empathizes the benefits of the natural environment for human beings. This classification is grounded in a general view about the relationship between human beings and nature (Stokols, 1990; White, 1967).

A different classification has been proposed by Stern and Dietz (1994). In one of the most influential works on the role of values in environmental concern, these authors provide a tripartite classification of values (social- altruistic, biospheric, and egoistic) that "may affect beliefs about the consequences of attitude objects for the things an individual values and thus have consequences for that individual's attitudes and behavior" (Stern \& Dietz, 1994, p. 67). The later-developed Value-Belief- 
Norm Model suggests that egoistic values lead people to be concerned about environmental issues that affect them personally, social-altruistic values lead people to be concerned about environmental issues that affect human groups, and biospheric values lead people to be concerned about environmental issues that affect nonhuman beings. Referring to the relationship between the two classifications, Thompson and Barton (1994) argue that egoistic and social-altruistic values are similar to anthropocentric values, whereas biospheric values are similar to ecocentric values. A slightly different interpretation is offered by Amérigo, Aragonés, Sevillano, and Cortés (2005), who have found that ecocentric values underlie two dimensions: an egobiocentric dimension for which nature is valued in relation to physical and psychological benefits for the self and a biospheric dimension for which nature is valued on its own. Following Stern and Dietz's (1994) theoretical model, Schultz $(2000,2001)$ developed an Environmental Motives Scale for assessing the set of valued objects on which people base their environmental concern. The author identified three sets of valued objects in an English-speaking sample: egoistic (me, my future, my lifestyle, my health), altruistic (all people, my children, people in the community, children), and biospheric (animals, plants, marine life, birds). This structure of environmental concern was also found in 10 Spanish-speaking countries (Schultz, 2001) and in another 6 countries (Brazil, the Czech Republic, Germany, India, New Zealand, and Russia), as well as with other languages and cultures (Schultz et al., 2005).

\section{Empathy With the Environment}

One of the recent theoretical developments in psychological studies of environmental issues is a focus on the relationship between self and nature (Clayton \& Opotow, 2003; Schultz, 2000; Kals, Schumacher, \& Montada, 1999). The basic theory is that an individual's attitudes about environmental issues are grounded in the degree to which people view themselves as 
part of the natural environment. The degree to which an individual associates self with nature has implications for his or her environmental attitudes and behaviors. Schultz (2002) has provided an inclusion model for under-standing these self-nature relationships, which includes a cognitive (connectedness), affective (caring), and behavioral (commitment) component. The connectedness component refers to the degree of inclusion of nature in an individual's cognitive representation of self. The caring component refers to the degree of affection for nature. The commitment component refers to willingness to act in a proenvironmental way.

This theoretical perspective provides a framework for understanding the types of environmental concerns a person might develop. Research in this area has tried to influence the degree of closeness in the relationship between self and nature and to assess the outcomes of these manipulations. Opotow (1993) studied the effect of the animal's similarity to people, the animal's use to people, and the severity of conflict between people and the animal in the participant's scope of justice. Results demonstrated that providing information about the similarities between humans and nonhuman species influenced perceptions of fairness in human-nature conflicts but only in a low-conflict scenario. In addition, providing information about the valuable benefits of an animal for humans yielded a wider scope of justice than pro- viding information about the harmful consequences of an animal's action for humans. Similarly, Schultz (2000) experimentally induced empathy with the natural environment, via a perspective taking manipulation by showing different kinds of images related to nature (animals in nature, animals harmed in nature, and people in nature). The results showed a significant interaction effect between kind of image and empathy induction (perspective taking vs. objective). Specifically, he found that participants who had viewed an image of an animal harmed in nature, in a perspective-taking experimental condition, showed higher biospheric concern with nature than participants in the 
objective condition.

However, this research did not control for the dispositional empathy level of the participants, which could moderate the effect of this kind of experimental manipulation on environmental concern. Indeed, past research has shown a positive relationship between empathic dimensions and environmental concerns (Schultz, 2001). Following Davis (1996), "empathy is broadly defined as a set of constructs having to do with the responses of one individual to the experiences of another" (p. 12). According to the multidimensional approach to empathy proposed by this author, a prototypical empathy episode could be described in terms of the antecedents (characteristics of the observer, target, or situation), processes (noncognitive, simple cognitive, and advanced cognitive), intrapersonal outcomes (cognitive and affective behavior not manifested in overt behavior), and interpersonal outcomes (behavioral responses). A large body of literature has documented an association between environmental concern and sociodemographic variables such as gender or race (e.g., Kalof, Dietz, Guagnano, \& Stern, 2002), personal variables such as per- sonal values, authoritarianism, or antisocial behaviors (Stern, Dietz \& Kalof, 1993; Schultz \& Stone, 1994; Corral-Verdugo, Frías-Amenta, \& GonzalezLomelí, 2003), and situational variables such as physical context (e.g. Corraliza \& Berenguer, 2000). However, a personal variable moderator effect of sociodemographic or situational variables has not been used to explain inconsistencies in research results.

The aim of the present study was to test the effect of a perspective taking manipulation on environmental concerns, and the moderating role of dispositional empathy on this effect. In the light of results in previous research (Schultz, 2000), we hypothesized that watching harmed animals from the animal's perspective would be associated with higher levels of biospheric and altruistic concern. We examined the effect on egoistic concerns too. As a tentative hypothesis, we expected a lower level of egoistic concern for participants 
who watched harmed animal slides from the animal's perspective. In general, participants with higher levels of dispositional empathy should have higher levels of biospheric concern when watching harmed animal slides from the animal's perspective.

This current study was designed to provide the participants with an empathic episode. Individual differences in empathy (antecedents), the "tendency to engage in empathy-related processes or to experience empathic outcomes” (Davis, 1996, p. 14), were measured by the Interpersonal Reactivity Index Scale (Davis, 1983). Perspective taking (process), "the attempts by one individual to understand another by imagining the other's perspective" (Davis, 1996, p. 17), was manipulated via instructional sets, and environmental concern (intrapersonal outcome) was measured with the Environmental Motives Scale (Schultz, 2000).

\section{Method}

\section{Participants}

We used a sample of 193 Spanish psychology students, 154 female and 39 male. The median age was 21 . The participants were paid $3.00 €$ for a 25 -minute session. We obtained a minimum sample of 120 subjects, which provided sufficient power (.80) to detect medium regression coefficients with 10 predictors (Cohen, 1988).

\section{Materials}

The stimuli were 10 color slides used in previous research (Schultz, 2000): five slides represented harmed animals (a seal caught in a fishing net, an eagle on a smoky factory smokestack, a deer knocked down by a car, a bear in a trash pile, a lioness being operated on) and five other slides represented animals in nature (a caribou on a hill, gorillas in a forest, a bear, a rhinoceros on a savannah, a breaching whale). 
The mean size of the images was $14 \square 20 \mathrm{~cm}$ on-screen, and the images were presented over a grey back- ground on a 17 " SVGA color monitor in 32-bit color. Distance from the monitor was $100 \mathrm{~cm}$. PowerPoint software was used.

\section{Measures}

The study used both a pretest and posttest questionnaire. Items in the questionnaire included the following:

- An open-ended question about "the environmental problem that concerns you the most and why" and the demographic variables of age and gender.

- Spanish version ${ }^{1}$ (Pérez-Albéniz, De Paúl, Etxeberría, Paz, \& Torres, 2003)

of the Interpersonal Reactivity Index (IRI; Davis, 1983). The IRI is com- posed of four 7-item subscales: A cognitive dimension measured by the Perspective Taking subscale, "tendency to spontaneously adopt the psychological point of view of others in everyday life," and the Fantasy subscale, "tendency to imaginatively transpose oneself into fictional situations;" an affective dimension measured by the Empathic Concern subscale, "tendency to experience feelings of sympathy and compassion for unfortunate other," and the Personal Distress subscale, "tendency to experience distress and discomfort in response to extreme distress in others” (Davis, 1996, p. 57).

- Manipulation check items: 1. "To what extent did you try to imagine how

the subjects were feeling?” 2. "To what extent did you objectively observe the subjects in the images?” 3. "To what extent did you take the perspec- tive of the subjects in the images?" 4. "To what extent did you remain detached from the subjects in the images?" Items were rated on a 9-point scale from 1 (not much) to 9 (very much). The exact question wording is shown 
in Appendix A.

- Environmental Motives Scale (Schultz, 2000) with three dimensions:

egoistic, altruistic, and biospheric concerns. The exact question wording is shown in Appendix B.

\section{Procedure}

Participants were directed individually to a testing room in the Social Psychology Laboratory. Participants were randomly assigned to view one of the two kinds of images, animal in nature and harmed animal, and one of the three experimental instructions: perspective taking, objective, or no instruction. See Appendix C for exact wording of instructions. Before begin- ning the experimental session, participants completed the pretest portion of the questionnaire: An open-ended question, some demographic variables, and the IRI.

Afterwards, the researcher collected the questionnaire, turned off the lights, and began the presentation of images. Instructions were given on the first slide. Each image remained on-screen for 30 seconds, with a 5- second interval between images. After the experimental session, partici- pants completed the second part of the questionnaire: four manipulation check items, the Environmental Motives Scale, and several other environ- mental attitudes measures.

\section{Results}

\section{Initial Analysis}

Means and standard deviations for the IRI subscales and intercorrelations among the IRI subscales and Environmental Motives Scale for the total sample are shown in Table 1. The highest and most significant correlation occurred in comparing the personal distress subscale with the biospheric and egoistic concern subscales. Based on this finding, we used this subscale as the primary measure of empathy. The altruistic 
concern subscale had no significant correlations with any of the IRI subscales, and it was deleted from subsequent analysis. Cronbach's alpha reliabilities, shown in Table 1, for the four IRI subscales and Environmental Motives Scale ranged from .70 to .89 .

\section{Table 1}

Means, Standard Deviations, and Intercorrelations Between IRI Subscales and Environmental Concern Subscales

\begin{tabular}{|l|l|l|c|c|l|c|}
\hline Subscale & Biospheric & Altruistic & Egoistic & $M$ & $S D$ & $\alpha$ \\
\hline $\begin{array}{l}\text { 1. Perspective } \\
\text { taking }\end{array}$ & .008 & .043 & -.041 & 3.74 & .54 & .70 \\
\hline 2. Fantasy & -.120 & .042 & .130 & 3.74 & .67 & .82 \\
\hline $\begin{array}{l}\text { 3. Empathic } \\
\text { concern }\end{array}$ & $-.182^{*}$ & .119 & $.157^{*}$ & 4.06 & .48 & .71 \\
\hline $\begin{array}{l}\text { 4. Personal } \\
\text { distress }\end{array}$ & $-.215^{*}$ & .128 & $.196^{* *}$ & 2.80 & .67 & .75 \\
\hline$\alpha$ & .89 & .77 & .84 & & & \\
\hline
\end{tabular}

Note: Centered scores. $N=193 .{ }^{*} p<.05 .{ }^{* *} p<.01$.

Manipulation check. A 3 (perspective, objective, no instruction) X 2 (image type) analysis of variance was performed for each manipulation check item. All analyses showed a significant main effect for kind of task, $F(2,187)=$ 20.465, $p<.001$ for Item $1 ; F(2,187)=22.758, p<.001$ for Item $3 ; F(2,187)=11.135, p<.001$ for Item 4 , except for Item $2, F(2,187)=0.50, p=.952$. Post hoc tests showed significant differences in the expected direction for perspective taking, objective, and no instruction, $\mathrm{M}=7.4 \mathrm{M}$ $=5.3$, and $\mathrm{M}=6.3$ for Item $1 ; \mathrm{M}=7.1, \mathrm{M}=4.9$, and $\mathrm{M}=$ 6.1 for Item 3; $M=3.3, M=4.4$, and $M=2.8$ for Item 4. Kind of image showed a significant main effect for check Item 3 and $4, F(1,187)=10.571, p=.001$ and $F(1,187)=$ 15.856, $p<.001$, respectively. Post hoc tests showed 
significant differences in the expected direction for animal in nature and harmed animal, $\mathrm{M}=5.6$ and $\mathrm{M}=6.5$ for Item 3 and $M=4.1$ and $M=3.0$ for Item 4. No interaction effect was found $F(2,187)=1.342, p=.264$ for Item $1 ; F(2,187)=$ $1.164, p=.315$ for Item $2 ; F(2,187)=2.384, p<.095$ for Item $3 ; F(2,187)=.551, p=.577$ for Item 4 . For Items 1,3 , and 4 , eta- squared was .20, .25, and .18. The check Item $2-$ "To what extent did you objectively observe the subjects in the images?"-had a homogeneous response for all experimental conditions (eta-squared $=.01$ ). We attribute this to the awkward wording of the item; participants likely interpreted objectively to mean "look carefully."

\section{Moderated Regression Analysis}

As described earlier, we selected personal distress as the primary mea- sure of empathy. The choice of personal distress is further supported by the content domain of the subscale items. Feelings of anxiety and discomfort in emotional settings, the objective of the personal distress subscale, could be produced in two of experimental conditions: harmed animal and perspective taking task.

A moderated regression analysis was conducted for each criterion variable: biospheric and egoistic concern. We used the procedure recommended by Aiken and West (1991) to test a continuous moderator variable effect within levels of categorical variables. This involved a three-step hierarchical regression analysis for each criterion variable.

Two dummy variables were used to code the two predictor variables. For kind of image, $A$ dummy variable, animal in nature $=0$ was used as reference category and $A_{1}=1$ for harmed animal. For kind of task, $B$ dummy variable, no instruction $=0$ was used as reference category, $B_{1}=1$ for objective task, and $\mathrm{B}_{2}=1$ for perspective taking task.

In all analyses, kind of image (animal in nature vs. harmed animal), kind of task (no instruction, objective, or perspective 
taking) and level of personal distress as the continuous moderator variable, were used to predict environmental concern (biospheric and egoistic). Following Aiken and West (1991), all lower level interaction terms were introduced first.

Biospheric concern was regressed on kind of image, kind of task, and personal distress moderator at the first step; two-way interaction terms (categorical variables $\mathrm{X}$ personal distress) at the second step; three-way inter- action terms (kind of animal $\mathrm{X}$ kind of task X personal distress) at the third step. We conducted the same analysis for egoistic concern. A moderator effect would be obtained if any of the interaction regression coefficients were significant, which would add to the explained variance.

Biospheric concern. The results of the analyses for biospheric concern are shown in Table 2. The first-order effects were significant and positive for harmed animal $(b=.28 ; p=.025)$ and significant negative for personal distress $(b=-.20 ; p=$ .004 ). Images of harmed animals were related to higher levels of biospheric concern. Higher levels of personal distress were associated with lower levels of biospheric concern. The loworder interactions were significant in a positive direction for harmed animal and perspective taking task $(b=.541, t(181)=$ $2.496, p=.02$ ). Presenting a harmed animal in the perspective taking condition was related to higher biospheric concern (see Figure 1, left). The highest-order interaction for harmed animal, objective task, and personal distress was also significant. This three- way interaction was explored using a simple slope analysis (Aiken \& West, 1991), in which the effect of harmed animal and objective task on biospheric concern were examined as a function of the value of personal dis- tress (one standard deviation above the mean vs. one standard deviation below the mean). For low personal distress level subjects in the objective condition, viewing a harmed animal was related to a high score on bios pheric concern $(b=$ $.631, t(181)=2.006, p=.05)$. On the contrary, for low personal distress level subjects in the no instruction condition, 
viewing a harmed animal was related to lower levels of biospheric concern $(b=-.523, t(181)=1.765, p<.10)$, see Figure 2, left. Kind of animal, kind of task, and personal distress tendencies accounted for a combined $13.6 \%$ of the variance in biospheric concern. 
Table 2

\begin{tabular}{|c|c|c|c|c|c|c|c|c|}
\hline \multicolumn{9}{|c|}{ Summary of Hierarchical Regression Analysis for Variables Predicting Environmental Concern $(N=193)$} \\
\hline \multirow[b]{2}{*}{ Step } & \multirow[b]{2}{*}{ Variable Entered } & \multicolumn{3}{|c|}{$b^{\mathrm{a}}$} & \multirow[b]{2}{*}{$R^{2}$} & \multirow[b]{2}{*}{ Model F } & \multirow[b]{2}{*}{$\Delta R^{2}$} & \multirow[b]{2}{*}{$\Delta F$} \\
\hline & & Step 1 & Step 2 & Step 3 & & & & \\
\hline \multicolumn{9}{|c|}{ Biospheric concern $^{\text {b }}$} \\
\hline \multicolumn{9}{|c|}{1.} \\
\hline & Constant $\left(\mathrm{b}_{0}\right)$ & -.040 & .177 & .185 & .076 & $3.863 * *$ & & \\
\hline & Harmed animal $\left(\mathrm{b}_{1}\right)$ & $.282 *$ & -.141 & -.105 & & & & \\
\hline & Objective task $\left(\mathrm{b}_{2}\right)$ & -.135 & $-.422 *$ & $-.439 *$ & & & & \\
\hline & $\begin{array}{l}\text { Perspective-taking task } \\
\left(\mathrm{b}_{3}\right)\end{array}$ & -.072 & $-.419+$ & $-.427 *$ & & & & \\
\hline & Personal distress $\left(\mathrm{b}_{4}\right)$ & $-.204 * *$ & $-.355^{*}$ & $-.536 * *$ & & & & \\
\hline \multicolumn{9}{|c|}{ 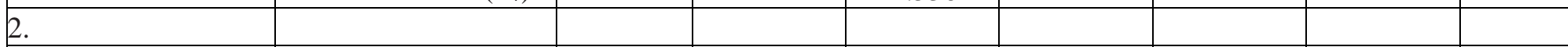 } \\
\hline & $\begin{array}{l}\text { Harmed animal } \mathrm{x} \\
\text { objective task }\left(\mathrm{b}_{5}\right)\end{array}$ & & $.546+$ & $.531+$ & .117 & $2.694 * *$ & .041 & 1.702 \\
\hline & $\begin{array}{l}\text { Harmed animal } \mathrm{x} \\
\text { perspective-taking task } \\
\left(\mathrm{b}_{6}\right)\end{array}$ & & $.682 *$ & $.646^{*}$ & & & & \\
\hline & $\begin{array}{l}\text { Harmed animal } \mathrm{x} \\
\text { personal distress }\left(\mathrm{b}_{7}\right)\end{array}$ & & .103 & $.625+$ & & & & \\
\hline & $\begin{array}{l}\text { Objective task } \mathrm{x} \\
\text { personal distress }\left(\mathrm{b}_{8}\right)\end{array}$ & & .357 & $.805^{*}$ & & & & \\
\hline & $\begin{array}{l}\text { Perspective-taking task } \\
\text { x personal distress }\left(\mathrm{b}_{9}\right)\end{array}$ & & .048 & .321 & & & & \\
\hline
\end{tabular}




\begin{tabular}{|c|c|c|c|c|c|c|c|c|}
\hline \multicolumn{9}{|c|}{ Summary of Hierarchical Regression Analysis for Variables Predicting Environmental Concern $(N=193)$} \\
\hline \multirow[b]{2}{*}{ Step } & \multirow[b]{2}{*}{ Variable Entered } & \multicolumn{3}{|c|}{$b^{\mathrm{a}}$} & \multirow[b]{2}{*}{$R^{2}$} & \multirow[b]{2}{*}{ Model F } & \multirow[b]{2}{*}{$\Delta R^{2}$} & \multirow[b]{2}{*}{$\Delta F$} \\
\hline & & Step 1 & Step 2 & Step 3 & & & & \\
\hline \multicolumn{9}{|l|}{3.} \\
\hline & $\begin{array}{l}\text { Harmed animal } \\
\text { objective task } \mathrm{x} \\
\text { personal distress }\left(\mathrm{b}_{10}\right)\end{array}$ & & & $-.932 *$ & .136 & $2.599 * *$ & .019 & 2.036 \\
\hline & $\begin{array}{l}\text { Harmed animal } \mathrm{x} \\
\text { perspective-taking task } \\
\mathrm{x} \text { personal } \\
\text { distress }\left(\mathrm{b}_{11}\right)\end{array}$ & & & -.589 & & & & \\
\hline \multicolumn{9}{|c|}{ Egoistic concern $^{\mathrm{b}}$} \\
\hline \multirow[t]{5}{*}{1.} & Constant & -.114 & $-.276 *$ & $-.284 *$ & .063 & $3.142^{*}$ & & \\
\hline & Harmed animal & -.147 & .163 & .125 & & & & \\
\hline & Objective task & .135 & $.327 *$ & $.344 *$ & & & & \\
\hline & Perspective-taking task & -.028 & .251 & .260 & & & & \\
\hline & Personal distress $^{\mathrm{b}}$ & $.187 * *$ & $.369 *$ & $.615^{* * *}$ & & & & \\
\hline \multicolumn{9}{|l|}{2.} \\
\hline & $\begin{array}{l}\text { Harmed animal x } \\
\text { objective task }\end{array}$ & & -.360 & -.344 & .103 & $2.329 *$ & .040 & 1.636 \\
\hline & $\begin{array}{l}\text { Harmed animal } \mathrm{x} \\
\text { perspective-taking task }\end{array}$ & & $-.541 *$ & $-.505^{*}$ & & & & \\
\hline
\end{tabular}




\begin{tabular}{|c|c|c|c|c|c|c|c|c|}
\hline \multicolumn{9}{|c|}{ Summary of Hierarchical Regression Analysis for Variables Predicting Environmental Concern $(N=193)$} \\
\hline \multirow[b]{2}{*}{ Step } & \multirow[b]{2}{*}{ Variable Entered } & \multicolumn{3}{|c|}{$b^{\mathrm{a}}$} & \multirow[b]{2}{*}{$R^{2}$} & \multirow[b]{2}{*}{ Model F } & \multirow[b]{2}{*}{$\Delta R^{2}$} & \multirow[b]{2}{*}{$\Delta F$} \\
\hline & & Step 1 & Step 2 & Step 3 & & & & \\
\hline & $\begin{array}{l}\text { Harmed animal } \mathrm{x} \\
\text { personal distress }\end{array}$ & & -.141 & $-.675 * *$ & & & & \\
\hline & $\begin{array}{l}\text { Objective task } \mathrm{x} \\
\text { personal distress }\end{array}$ & & -.220 & $-.674 * *$ & & & & \\
\hline & $\begin{array}{l}\text { Perspective-taking task } \\
\text { x personal distress }\end{array}$ & & & -.080 & -.362 & & & \\
\hline \multicolumn{9}{|l|}{3.} \\
\hline & $\begin{array}{l}\text { Harmed animal x } \\
\text { objective task x } \\
\text { personal distress }\end{array}$ & & & $.945^{* *}$ & .138 & $2.639 * *$ & .035 & $3.724 *$ \\
\hline & $\begin{array}{l}\text { Harmed animal } \mathrm{x} \\
\text { perspective-taking task } \\
\mathrm{x} \text { personal distress }\end{array}$ & & & $.609+$ & & & & \\
\hline
\end{tabular}

a. Unstandardised coefficients (West, Aiken, \& Krull, 1996) except for personal distress.

b. Centered variable.

$+p<.10 .{ }^{*} p<.05 .{ }^{* *} p<.01 .{ }^{* * *} p<.00$ 
Figure 1

Centered Mean Scores of Biospheric and Egoistic Concern for King of Image and Perspective Taking Task

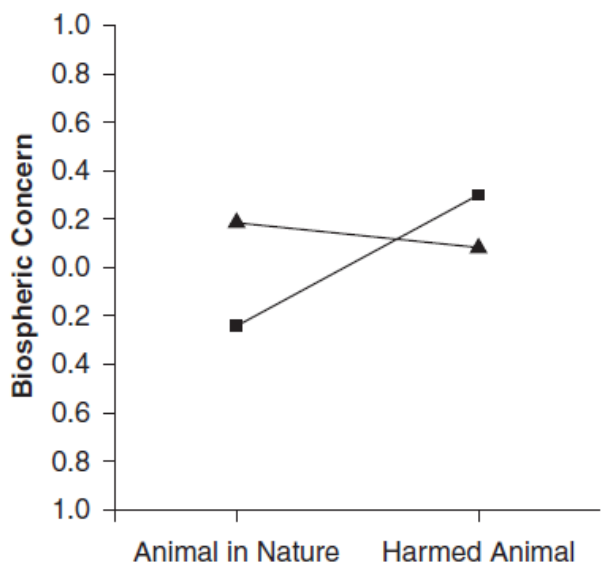

Kind of Image

- No instruction

- Perspective taking

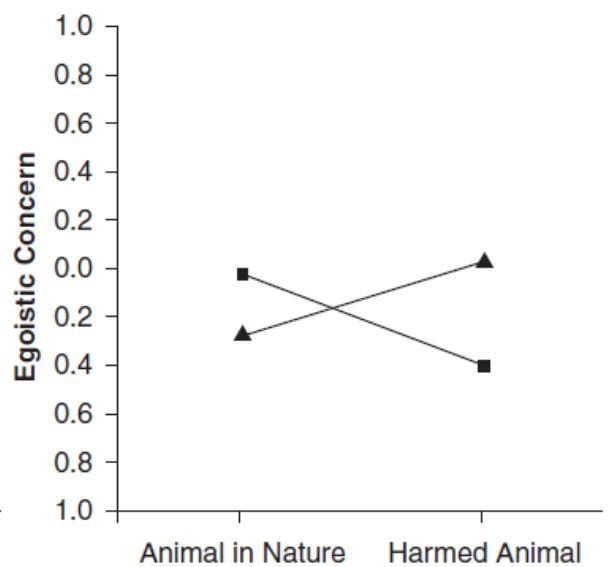

Kind of Image

- No instruction

- Perspective taking 
Figure 2

\section{Centered Means Scores of Biospheric and Egoistic Concern for Kind of Image, Kind of Task, and Low Personal Distress Level Subjects}
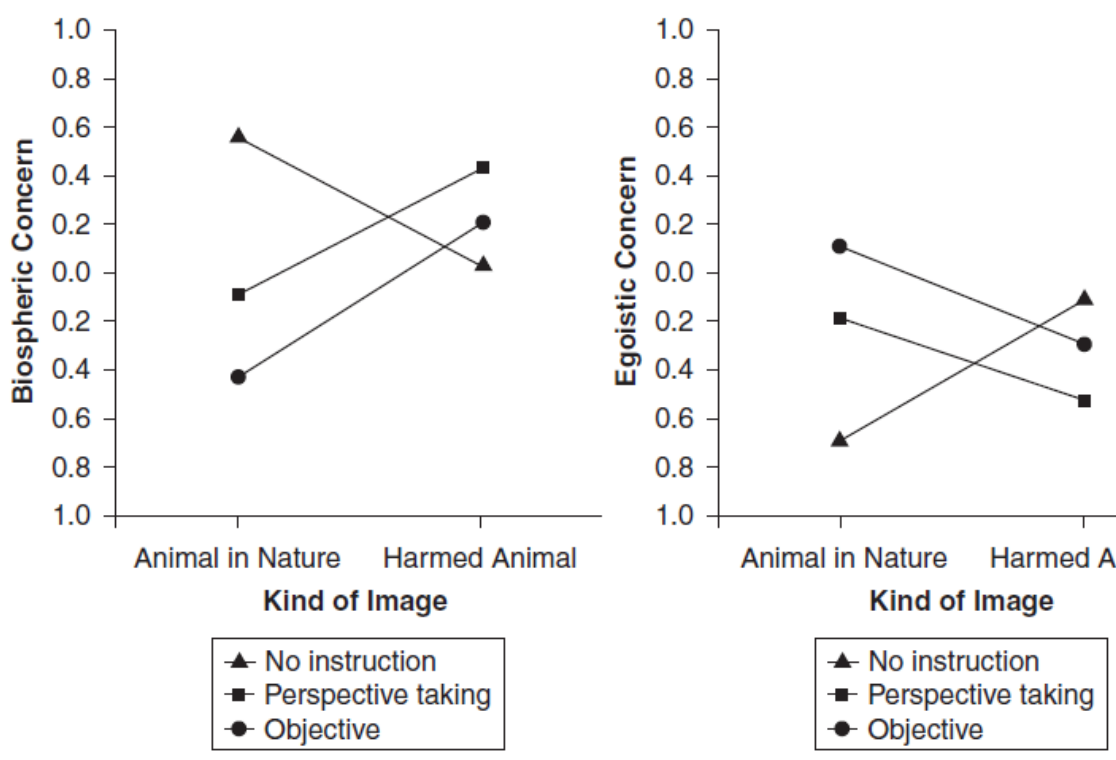

Egoistic concern. The results of analyses for egoistic concern are shown in Table 2 . The first-order effects were significant positive for personal dis- tress $(p=.009)$.

Higher levels of personal distress were related to higher egoistic concern. The low-order interactions were significant in a negative direction for the harmed animal and perspective taking task $(b=-.379, t(181)$ $=2.35, p<.05)$. Presenting a harmed animal under perspective taking conditions was related with a lower egoistic concern (see Figure 1, right). The highest-order interaction was significant for harmed animal, objective task, and personal distress. Simple slopes analysis found a trend for low personal distress level subjects who viewed a harmed animal in an objective task. These subjects scored lower on egoistic concern $(b=-.40, t$ 
(181)

$=1.702, p<.10)$. On the contrary, for low personal distress level subjects, viewing a harmed animal in the no instruction condition was related to a high score on egoistic concern $(b=.577, t(181)=2.571, p=.02)$, see Figure 2, right. Kind of animal, kind of task, and personal distress tendencies accounted for a combined $13.8 \%$ of the variance in egoistic concern.

\section{Discussion}

Several results from the reported experiment replicate and compliment previous studies. According to previous research (Schultz, 2000), participants who viewed a harmed animal from the animal's perspective showed higher levels of biospheric concern. Our results replicate this finding. In addition, we found that participants in such a situation (perspective taking and harmed) showed lower levels of egoistic concern - that is, participants who viewed a harmed animal from the animal's perspective scored higher in biospheric concern but they scored lower in egocentric concern.

Prior research on the use of perspective taking inductions has shown that taking perspective leads to a higher level of concern for the target and to greater levels of helping. For example, Batson et al. (1991) showed that students who were asked to take the perspective of a fellow student in need were considerably more concerned and more likely to help. In the study, Katie was experiencing a family crisis and having difficulty completing her final year at the university. Students who were asked to take Katie's perspective volunteered to help her at considerably higher rates (83\%) com- pared to students who were asked to remain objective (33\%). Batson et al. (1995) further showed that the empathy induced for an individual through a perspective taking manipulation can lead to an increased resource allocation for that individual, even at 
the detriment of the group. Our findings suggest that taking perspective can lead to an increase in concern for the entire group to which the individual belongs - not just the individualthat is, taking the perspective of a bear did not just lead to an increase in concern for the welfare of that specific bear nor to bears in general. Indeed, our measure of biocentric environmental concern did not even include an item about bears. Rather, taking perspective led to a general increase in concern for the welfare of living organism; items in the biocentric scale were plants, animals, marine life, and birds.

Results from the moderation analysis showed that the basic perspective taking effect was not moderated by dispositional empathy. However, we did find several moderated effects for the objective versus no instruction manipulations. First, we found a first-order effect of personal distress variable on both biospheric and egoistic concern. Higher levels of personal distress were related to lower levels of biospheric concern and higher levels of egoistic concern - that is, a dispositional variable affected in different manners to different kinds of concerns. Second, we found that the empathic affective dimension of personal distress moderated the relationship between an experimental proenvironmental situation (kind of task $\mathrm{X}$ kind of image) and both biospheric and egoistic environmental concerns - that is, the experimental proenvironmental situation affected different environmental concerns depending on personal distress tendency. This moderating effect was found specifically for participants with low levels of empathy (personal distress). When asked to remain objective while viewing an image of an animal harmed, low empathy participants scored lower on egoistic concerns and higher on biocentric concerns. There was no effect for moderation effect for perspective taking. The failure to find the predicted interaction could be explained in that the comparison group for the multiple regression analysis was a no- instruction, animal-in-nature condition. Thus, there was no difference between taking the perspective of a harmed animal and giving no instruction. Nevertheless, the slope of the effect was in the 
theoretical direction.

The results for personal distress suggest that the level of discomfort and anxiety that people feel in response to needy targets may play a role in under- standing the kind of environmental concern expressed by participants. The relationship between personal distress and environmental concern may come from a differential conceptualization of parallel and reactive outcomes, following the affective outcomes of an empathic situation, proposed by Davis (1996). A parallel outcome is "an actual reproduction in an observer of the target's feelings" (p. 18). A reactive outcome is defined as "affective reactions to the experiences of others which differ from the observed affect" (p. 18). Following this distinction, parallel outcomes would be more self- centered reactions (e.g., distress), whereas reactive outcomes would be more other-oriented (e.g., concern for other). High tendency to feel distress was related with a high score on egoistic concern (self-centered) and a low score on biospheric concern (other-oriented). So it could be inferred that participants who have a tendency to feel stress in empathic situations tend to be concerned for environmental problems that affect them personally, and less concerned for environmental problems that affect all living things. Past research has reported a positive significant correlation between biospheric concern and perspective taking tendencies (Schultz, 2001). Surprisingly, we didn't find this result in the current investigation $(r=.008, n s)$. However, we did find empirical evidence that taking the perspective of a harmed animal leads to higher levels of biospheric concern and decreased levels of egoistic concern. To clarify this point, we examined the correlations between the perspective taking subscale and biospheric concern scores in the control group $(n=48)$. The control group only completed the questionnaire without any experimental manipulation. In the same way as the experimental group, a 30-minute period was taken between completing IRI scale and Environmental Motives Scale. This group was excluded from the precedent statistical analysis. 
Surprisingly, a significant negative correlation was found $(r=$ $-.306, p<.05$ ). Yet in our experimental results, perspective taking tendencies were not related with environmental biopheric concern. These results may potentially be explained by differences in research procedures. In the first case, the order of scales presentation was the Environmental Motives Scale (Schultz, 2000); Dunlap, Van Liere, Mertig \& Howell's revised version of NEP scale; and then IRI. In the second case, IRI was administrated in the first place and after a 30minute period, the Environmental Motives Scale was administrated. In the first case, the measurement context could sensitize participants to environmental concern and empathy because both concepts imply concern. Similar explanations were given by Wiseman and Bogner (2003) in a research about ecological values and personality traits. In addition, cultural differences could have played a role in these inconsistent findings.

Biospheric and egoistic concerns were affected differently for both the experimental proenvironmental situation and personal distress moderator variable. The experimental proenvironmental situation led to higher levels of biospheric concern and lower levels of egoistic concern. Personal distress led to lower levels of biospheric concern and higher levels of egoistic concern. This distinct functioning would support the theoretical distinction between biospheric and egoistic values proposed by Stern and Dietz (1994). In the same way, our findings would support the ecocentric and anthropocentric classification proposed by Thompson and Barton (1994) too, because those authors consider egoistic value similar to anthropocentric value and biospheric value similar to ecocentric value.

Based on our results, it might be tempting to use these principles in marketing or ad campaigns. Getting viewers (or listeners) to take the perspective of a target, with the goal of increasing concern for the target and motivating behavior. For example, a recent $\$ 10$ million statewide ad campaign in California was developed around the theme "Recycle. It's 
good for the bottle. It's good for the can" and featured ads about "When cans dream" (www.bottlesandcans.com). Similarly, a current National Spanish Govern- mental advertising campaign ${ }^{2}$ about recycling glass states, "Glass could have several lives. Recycle it” (Ecovidrio, 2005). In both sets of ads, bottles are depicted expressing the desire to be recycled. Given our results showing that perspective taking can lead to an increase in concern for the target group, this first-person advertising approach seems reasonable.

However, the approach has not been tested (at least, not in the peer reviewed literature), and we are skeptical that such first-person ad approaches will induce a concern for the welfare of inanimate objects. Perspective taking manipulations have been shown repeatedly to induce concern and helping behavior for another person (Batson, Batson, Slingsby, et al., 1991; Batson, Batson, Todd, et al., 1995; Batson, Dyck, et al., 1988), and our results show that this can generalize to nonhuman animals. But we do not believe that it will work for inanimate objects. It would seem that the effect is predicated on a basic value of life, or a general concern for the welfare of another living being (e.g., Schwartz, 1977). Although we do not want to see another person suffer or an animal suffer, this same level of caring does not apply to inanimate objects (similar to a glass bottle). In the same vein, Opotow's research on the "scope of justice" suggests that concern and helping are linked to objects that fall within our "psychological boundary to which moral norms, rights, and considerations of fairness apply" (Opotow \& Brook, 2003, p. 252). From this perspective, helping and concern are limited to those objects (people, animals, plants, etc.) that we include within our scope of justice. A bottle would not fall within my scope of justice, so I'm generally not motivated to care. But this remains a question for future research. 


\section{Appendix A}

\section{Spanish Version Check Items}

1. ¿En qué medida ha intentado imaginar los sentimientos y la situación de los animales que se le han presentado?

2. ¿Hasta qué punto ha observado detenidamente las fotografías que se le han presentado?

3. ¿Hasta qué punto se ha puesto en el lugar de los animales que se le han presentado?

4. ¿En qué medida se ha mantenido imparcial ante las fotografías que se le han presentado?

\section{Appendix B}

\section{Spanish Version of Environmental Motives Scale (Schultz, 2000)}

Por favor, conteste a las siguientes cuestiones usando una escala de 7 puntos; donde 1 significa ninguna importancia para usted y 7 significa máxima importancia para usted.

Según su opinión: en qué medida valora usted como importantes las CONSECUENCIAS que producen los problemas ambientales sobre los temas siguientes:

\begin{tabular}{|c|c|c|}
\hline La vida & _Las aves_ & _La vida \\
\hline vegetal & _Los & acuática \\
\hline _Mi salud & animals & __Mi futuro \\
\hline _Mi estilo & _ Todas las & $\ldots \mathrm{Mi}$ \\
\hline de vida & personas & persona \\
\hline _Los niños_ & _Los & L Los \\
\hline & vecinos_ & familiares \\
\hline
\end{tabular}




\section{Appendix C Spanish and English Task Instructions}

\section{Perspective Taking Instruction}

Spanish versión. A continuación se le va a presentar una serie de fotografías, al verlas: Trate de tomar el punto de vista de los sujetos que aparecen en las fotografías, imaginando cómo se sienten acerca de lo que les ocurre. Piense acerca de las reacciones de los sujetos y visualice clara y vívidamente cómo se sienten. Trate de imaginar cómo se sienten los sujetos en las imágenes. Mientras las ve, imagínese a sí mismo sintiendo exactamente lo que ellos sienten. Intente no preocuparse por atender a toda la información que se presenta, sólo imagine qué siente el sujeto en esa situación.

English version. Next, a series of photographs will be presented, upon seeing them: Try to take the perspective of the subjects that appear in the pictures, imagining how they are feeling about what is happening. Think about the reactions of the subjects and visualize clearly and vividly how they feel. Try to imagine how the subjects in the pictures feel. While you view them, picture to yourself just how they feel. Try not to concern your- self with attending to all the information presented, just imagine how the subjects feel in that situation.

\section{Objective Instruction}

Spanish versión. A continuación se le va a presentar una serie de fotografías, al verlas: Intente tomar una postura neutral, siendo tan objetivo como sea posible con los sujetos que aparecen en las fotografías. Mire atentamente a los sujetos que se muestran en cada imagen y observe cuidadosamente las peculiaridades, posturas, movimientos y expresiones faciales de los sujetos. Esté atento a lo que el sujeto hace, sea lo que sea. No se 
preocupe por las emociones que puedan tener los sujetos; sólo concéntrese en las imágenes objetivamente.

English version. Next, a series of photographs will be presented, upon seeing them: Try to take a neutral perspective, being as objective as possible about the subjects that appear in the pictures. Look closely at the subjects within each image and make careful observations about the subjects' mannerisms, postures, movements, and facial expressions. Notice exactly what the subject is doing, whatever it is. Do not let yourself become caught up in imagining what the subject has been through. Just concentrate on the images objectively.

\section{No Instruction}

Spanish version. A continuación se le va a presentar una serie de fotografías, obsérvelas atentamente.

English version. Next, a series of photographs will be presented, look at them closely.

\section{Notes}

1. The only difference between the English and Spanish versions was item 13. In the Spanish version, item 13 was located on the empathic concern subscale, whereas it appears on the personal distress subscale in the English version.

2 We thank Beatriz Cortés for suggesting this ad campaign. 


\section{References}

Aiken, L. S., \& West, S. G. (1991). Multiple regression: testing and interpreting interactions.

Thousand Oaks, CA: Sage.

Amérigo, M., Aragonés, J. I., Sevillano, V. \& Cortés, B.

(2005). La estructura de las creencias sobre la problemática medioambiental [The structure of beliefs about environmental con- cern]. Psichotema, 17, 246-251.

Batson, C. D., Batson, J. G., Slingsby, J. K., Harrell, K. L., Peekna, H. M., \& Todd, R. M. (1991). Empathic joy and the empathy-altruism hypothesis. Journal of Personality and Social Psychology, 61, 413-426.

Batson, C. D., Batson, J. G., Todd, R. M., Brummett, B. H., Shaw, L. L., \& Aldeguer, C. M. R. (1995). Empathy and the collective good: caring for one of the others in a social Dilemma. Journal of Personality and Social Psychology, 68, 619-631.

Batson, C. D., Dyck, J. L., Brandt, J. R., Batson, J. G.,

Powell, A. L., McMaster, M. R., \& Griffitt, C. (1988). Five studies testing two new egoistic alternatives to the empathyaltruism hypothesis. Journal of Personality and Social Psychology, 55, 52-77.

Clayton, S., \& Opotow, S. (2003). Identity and the natural environment. Cambridge, MA: MIT Press.

Cohen, J. (1988). Statistical power analysis for the behavioral sciences. Hillsdale, NJ: Lawrence Erlbaum.

Corral-Verdugo, V., Frías-Amenta, M., \& Gonzalez-Lomelí, D. (2003). On the relationship between antisocial and antienvironmental behaviors: An empirical study. Population and Environment: A journal of Interdisciplinary Studies, 24, 273-286.

Corraliza, J. A., \& Berenguer, J. (2000). Environmental values, beliefs, and actions: a situational approach. Environment and Behavior, 32, 832-848. 
Davis, M. H. (1983). Measuring individual differences in empathy: evidence for a multi- dimensional approach.

Journal of Personality and Social Psychology, 44, 113-126. Davis, M. H. (1996). Empathy: A social psychological approach. Boulder, CO: Westview. Dunlap, R. E., \& Van Liere, K. D. (1978). The new environmental paradigm. Journal of

Environmental Education, 9, 10-19.

Ecovidrio (2005). El vidrio puede tener muchas vidas.

Recíclalo [Glass could have several lives. Recycle

it].Retrieved December 30, 2005 from Ecovidrio

(http://www.ecovidrio.es/app/GeneralPaginas)

.asp?seccion=Newsletter.asp

Kaiser, F. G., \& Fuhrer, U. (2003). Ecological behavior’s dependency on different forms of knowledge. Applied Psychology: An International Review, 52, 598-613.

Kalof, L., Dietz, T., Guagnano, G., Stern, P. C. (2002). Race, gender and environmentalism: The atypical values and beliefs of White men. Race, Gender and Class, 9, 1-19. Kals, E., Schumacher, D., \& Montada, L. (1999). Emotional affinity toward nature as a moti- vational basis to protect nature. Environment and Behavior, 31, 178-202.

Milbrath, L. W. (1986). Environmental beliefs and values. In M. G. Hermann (Eds.), Political psychology (97-138). San Francisco: Jossey-Bass.

Opotow, S. (1993). Animals and the scope of justice. Journal of Social Issues, 49, 71-86. Opotow, S., \& Brook, A. (2003). Identity and exclusion in rangeland conflict. In S. Clayton \&

S. Opotow (Eds), Identity and the natural environment (pp. 249-272). Cambridge, MA: MIT Press.

Pérez-Albéniz, A., De Paúl, J., Etxeberría, J., Paz, M., \&

Torres, E. (2003). Adaptación de Interpersonal Reactivity

Index (IRI) al español [Spanish version of Interpersonal

Reactivity Index (IRI)]. Psicothema, 15, 267-272.

Schultz, P. W. (2000). Empathizing with nature: the effects of 
perspective taking on concern for environmental issues. Journal of Social Issues, 56, 391-406.

Schultz, P. W. (2001). Assessing the structure of

environmental concern: Concern for self, other people, and the biosphere. Journal of Environmental Psychology, 21, 327-339.

Schultz, P. W. (2002). Inclusion with nature: The psychology of human-nature relations. In

P. Schmuck \& P. W. Schultz (Eds.), Psychology of

Sustainable Development (pp. 61-78). Norwell, MA: Kluwer Academic.

Schultz, P. W., Gouveia, V. V., Cameron, L., Tankha, G.,

Schmuck, P., \& Franek, M. (2005). Values and their

relationship to environmental concern and conservation behavior. Journal of Cross-cultural Psychology, 36, 457475.

Schultz, P. W., \& Stone, W. F. (1994). Authoritarianism and attitudes toward the environment.

Environment and Behavior, 26, 25-37.

Schwartz, S. H. (1977). Normative influences on altruism. In

L. Berkowitz (Eds.), Advances in experimental social psychology (Vol. 10, pp. 221-279). New York: Academic. Stern, P. C., \& Dietz, T. (1994). The value basis of environmental concern. Journal of Social Issues, 50, 65-84. Stern, P. C., Dietz, T., \& Kalof, L. (1993). Value orientations, gender, and environmental con- cern. Environment and Behavior, 25, 322-348.

Stokols, D. (1990). Instrumental and spiritual views of peopleenvironment relations. American Psychologist, 45, 641-646. Thompson, S. C. G., \& Barton, M. A. (1994). Ecocentric and anthropocentric attitudes toward the environment. Journal of Environmental Psychology, 14, 149-157.

Uzzell, D. L. (2000). The psycho-spatial dimensions of global environmental problems.

Journal of Environmental Psychology, 20, 307-318. 
West, S. G., Aiken, L. S., \& Krull, L. J. (1996). Experimental personality designs: Analysing categorical by continuous variable interactions. Journal of Personality, 64, 1-48. White, L. J. (1967). The historical roots of our ecological crisis. Science, 155, 1203-1207. Wiseman, M., \& Bogner, F. X. (2003). A higher-order model of ecological values and its relationship to personality. Personality an Individual Differences, 34, 783-794.

Verónica Sevillano is a $\mathrm{PhD}$ student at the Complutense University of Madrid (Spain) special- izing in environmental psychology. She received her BA from Complutense University in 2001. Her research interests include proenvironmental behaviors and attitudes, and spatial cognition.

Juan I. Aragonés is professor of social psychology at the Complutense University of Madrid, Spain. He has been working on subjects related to residential environment for more that a decade, mainly on housing for low-income groups. He is the author of chapters, articles, and papers connected with this field. Recent books include Residential Satisfaction (2002), and Environmental Psychology (Psicología ambiental. 2000, Pirámide). He has worked on research projects for Spanish Ministry of Education and Science. At present he is working on behavior in domestic fires and perception of environmental problems.

P. Wesley Schultz is professor of psychology at California State University, San Marcos. His research interests are in applied social psychology, particularly in the area of sustainable behavior. Recent books include Social Psychology: An Applied Perspective (2000, Prentice- Hall), Psychology of Sustainable Development (2002, Kluwer), and 
Attitudes and Opinions (2005, Lawrence Erlbaum). His current work focuses on social norms, and the importance of social norms in fostering sustainable behavior. He has worked on projects for a variety of orga- nizations, including the Environmental Protection Agency, National Institutes of Health, U.S. Department of Justice, and the California Integrated Waste Management Board. Email:

wschultz@csusm.edu.Web site:www.csusm.edu/schultz. 